\title{
ANALISIS SOSIOLOGI PROBLEM RUMAH TANGGA DALAM NOVEL ISTANA KEDUA KARYA ASMA NADIA
}

\author{
Heppy Lismayanti, H. Kamal Hasuna
}

\author{
Program studi penndidikan bahasa dan sastra Indonesia \\ STKIP PGRI Banjarmasin \\ email: heppylismayanti@stkipbjm.ac.id
}

\begin{abstract}
Abstrak
Penelitian ini berkenaan dengan problem rumah tangga yang terdapat dalam novel Istana Kedua. Tujuan penelitian ini adalah untuk (1) Mendeskripsikan bentuk problem yang terdapat pada novel Istana Kedua Karya Asma Nadia. (2) Mendeskripsikan faktor apa saja penyebab timbulnya problem pada novel Istana Kedua Karya Asma Nadia.

Pendekatan yang digunakan dalam penelitian ini adalah pendekatan sosiologis. Metode yang digunakan dalam penelitian ini adalah metode deskriptif analisis. Teknik pengumpulan data pada penelitian ini adalah teknik analisis teks dan teknik dokumentasi, dan teknik untuk menganalisis data adalah teknik deskriptif interpretatif.Sumber data yang dijadikan objek penelitian yaitu novel Istana Kedua Karya Asma Nadia yang diterbitkan oleh PT Gramedia Pustaka Utama, Oktober 2007.

Berdasarkan hasil penelitian diperoleh simpulan sebagai berikut: (1) Problem rumah tangga yang terjadi : (a) selingkuh: Pras telah menjalin hubungan dengan perempuan lain, suami telah menjalin hubungan dengan perempuan lain, suami Ratih telah berselingkuh dua kali, suami Lia berselingkuh di rumahnya sendiri, suami Ibu Arini berselingkuh dengan seorang perempuan malam. (b) poligami: Pras telah menikah lagi, Mas Yadi suami mbak Pur memiliki dua orang istri, suami Ina menikah lagi, pengorbanan seorang istri, karena suaminya menikah lagi, bapak Pras menikah lagi, suami Ibu Arini telah menikah lagi dengan teman sekolahnya. (c) perceraian: Lia dan suaminya bercerai. (2) Faktor penyebab timbulnya problem: (a) Fakor dari suami istri: Adanya masalah yang tersembunyi di antara suami istri, adanya masalah yang tersembunyi di antara suami istri, adanya masalah yang disembunyikan oleh suaminya kepada Ratih, kurangnya frekuensi pertemuan antara suami istri dapat mengakibatkan suami berselingkuh, istri tidak bisa merawat diri, kesalahan cara berpikir istri, istri yang tidak bisa memasak. (b) Faktor dari keluarga: Ibu mertua juga ikut diam dan tidak memberitahu bahwa suaminya berselingkuh. (c) Faktor dari orang luar: Adanya sosok perempuan yang mengaku sebagai istri Pras, seorang perempuan telah menaksir suaminya, kelalaian seorang istri dalam memperhatikan suaminya, sehingga perempuan lain masuk dalam rumah tangga, ada sosok anak kecil hasil dari pernikahan Bapaknya yang kedua, ada sosok perempuan yang menemui suaminya.
\end{abstract}

Kata kunci: problem rumah tangga, novel, sosiologi sastr

\section{Pendahuluan}

Karya sastra yang berbentuk novel sebagai wujud kreativitas dapat mengungkapkan aspek-aspek moral, religius, sosial budaya, psikologi, filosofis dan lain-lain. Novel adalah tulisan berupa karangan prosa yang panjang dan menceritakan sebuah kisah. Novel juga sebagai sebuah karya fiksi yang sering pula disebut dengan cerita yang berupa rekaan, hasil olahan pengarang berdasarkan pandangan, tafsiran, dan penilaiannya tentang peristiwa-peristiwa yang hanya berlangsung dalam khayalannya (Semi, 1993:31) 
Pada era ini telah banyak pengarang yang menghasilkan novel yang mengandung problem rumah tangga, karena pada dasarnya problem dan sastra saling berhubungan. Problem merupakan salah satu dorongan pengarang dalam menciptakan sebuah karya sastra. Problema rumah tangga ini telah mendapatkan tempat yang nyaman di hati pembacanya. Tak heran dengan carut-marutnya keadaan zaman sekarang yang terjadi dalam rumah tangga, sehingga pembaca ingin mencari bahan bacaan yang menyentuh sisi moral dan inspirasi bagi kaum perempuan, sehingga bisa mendapatkan kepuasan dan kenyamanan batin. Novel problem diharapkan memberikan tambahan pengetahuan dan ilham terhadap pembacanya, karena salah satu tujuan kehadiran karya sastra di tengah-tengah masyarakat pembaca adalah untuk meningkatkan harkat dan martabat manusia sebagai makhluk berbudaya, berpikir, dan berkebutuhan.

Berdasarkan uraian-uraian di atas, dapat diketahui bahwa betapapun banyak pengalaman dan permasalahan yang ditulis dalam sebuah novel, ia tetap harus memberikan sajian yang memberikan kenyamanan bagi pembacanya. Dengan membaca novel berarti menikmati sebuah cerita dan mendapatkan kepuasan batin, sehingga membaca novel juga merupakan suatu kegiatan yang memberikan pengetahuan sekaligus hiburan.

Novel istana kedua termasuk karya sastra yang dibuat dan dinikmati serta berisi problem rumah tangga yang mampu menyentuh hati pembacanya, namun tidak lupa menampilkan sisi hiburannya. Dalam novel ini, pengarang menciptakan tentang curahan hati perempuan yang mengalami problema rumah tangga dan buku ini bisa memberikan inspirasi bagi kaum perempuan.

Peneliti tertarik untuk mengangkat novel Istana Kedua karya Asma Nadia ini untuk mengkaji analisis sosiologi problem rumah tangga, karena dalam novel ini mempunyai daya tarik tersendiri ditinjau dari realitas kehidupan rumah tangganya dan mengingat dalam novel ini banyak kaum masyarakat meluapkan cerita atau curhat baik dalam email maupun dalam blognya Asma Nadia sehingga terciptalah buku Istana Kedua.

\section{Kajian Sosiologis}

Ratna (2015:59) menyatakan bahwa pendekatan sosiologis menganalisis manusia dalam masyarakat dengan proses pemahaman mulai dari masyarakat ke individu. Dasar filosofis pendekatan sosiologis itu sendiri, adanya hubungan hakiki antara karya sastra dengan masyarakat. Pendekatan sosiologis merupakan pendekatan yang mampu menjadi sangat dekat dengan masyarakat, karena pemahamannya yang mendasar mengenai kehidupan masyarakat.

\section{Pengertian Problem Rumah Tangga}

Problem adalah masalah yang menimbulkan perbedaan dalam suatu persoalan (Novia, 2006:548). Rumah tangga adalah segala sesuatu yang berhubungan dengan urusan kehidupan dan sesuatu yang berhubungan atau berkenaan dengan keluarganya (Novia, 2005:586). Problem rumah tangga adalah permasalahan yang terjadi di dalam suatu keluarga. Sebuah rumah tangga dapat 
dikatakan sejahtera dan bahagia, apabila rumah tangga tersebut telah mencapai kesuksesan dalam hidupnya, baik material maupun spiritual. Nilai-nilai kesuksesan tersebut tercermin dalam situasi penuh kebahagiaan dan ketentraman hidup bersama para anggota keluarga. Tampak pula di dalamnya keselarasan, keserasian dan keseimbangan hidup, sehingga dapat menjadi cermin bagi masyarakat sekelilingnya.

\section{Problem yang Terjadi}

Problem rumah tangga yang akan dikaji dalam penelitian ini mencakup berbagai macam masalah, yaitu sebagai berikut:

a) Selingkuh : suka menyembunyikan sesuatu untuk kepentingan sendiri atau tidak mau berterus terang (Novia, 2006:605).

b) Perceraian : perpisahan atau putus hubungan sebagai suami istri (Novia, 2006:284).

c) Poligami : hal perkawinan seorang lelaki dengan perempuan lebih dari satu orang (Novia, 2006:542).

\section{Faktor Penyebab Timbulnya Problem}

Novel memiliki tujuan untuk menemukan pesan yang ingin disampaikan oleh pengarang. Apabila dalam suatu karya sastra mengandung pesan masalah rumah tangga, maka sebenarnya di dalamnya terdapat lebih dari satu masalah yang ditimbulkan dalam rumah tangga. Faktor penyebab timbulnya problem dalam rumah tangga yang akan terjadi berupa masalah hidup, harkat martabat perempuan, dan sebagainya.

Novel adalah tulisan berupa karangan prosa yang panjang dan menceritakan sebuah kisah. Novel sebagai salah satu bentuk karya sastra dapat dengan bebas bercerita tentang kehidupan yang dialami oleh manusia dengan berbagai peraturan dan norma-norma dalam interaksinya dengan lingkungan, sehingga dalam karya sastra (novel) terdapat makna tertentu tentang kehidupan. Karya sastra termasuk dalam novel setiap pemunculannya mencerminkan suatu keadaan masyarakat tertentu. Zaidan, (2007:136) menjelaskan bahwa novel adalah jenis prosa yang mengandung unsur tokoh, alur, latar rekaan yang menggelarkan kehidupan manusia atas dasar sudut pandang pengarang dan mengandung nilai hidup, diolah dengan teknik lisan dan ragaan yang menjadi dasar konvensi penulisan.

Semi (1993:32) menjelaskan bahwa novel merupakan karya fiksi yang mengungkapkan aspek-aspek kemanusiaan yang lebih mendalam dan disajikan dengan halus. Novel mengungkapkan suatu konsentrasi kehidupan pada suatu saat yang tegang, dan pemusatan kehidupan yang tegas.

Abrams (dalam Nurgiyantoro, 2012:04) menyatakan bahwa novel adalah sebuah karya fiksi yang menawarkan sebuah dunia, sebuah model kehidupan yang diidealkan, dunia imajinatif yang dibangun melalui berbagai unsur intrinsiknya yang semuanya tentu saja bersifat imajinatif. Dari 
beberapa pendapat di atas dapat disimpulkan bahwa novel adalah karya sastra yang berbentuk prosa yang menceritakan tentang kehidupan sehari-hari dengan balutan imajinasi dan rekaan, serta mengandung nilai-nilai kehidupan. Novel disajikan dengan berbagai imajinasi, selain menjadi bacaan yang mengandung nilai kehidupan dan pengetahuan, novel diharapkan dapat menghibur hati para penikmatnya.

\section{Metode}

Pendekatan didefinisikan sebagai cara-cara menghampiri objek (Ratna, 2015:53). Tujuan pendekatan adalah pengakuan terhadap hakikat ilmiah objek ilmu pengetahuan itu sendiri. Dalam pendekatan terkandung manfaat penelitian yang akan diharapkan, baik secara teoretis maupun praktis, baik terhadap peneliti secara individu maupun masyarakat pada umumnya. Dalam penelitian ini, pendekatan yang peneliti gunakan untuk mengkaji novel Istana Kedua adalah pendekatan sosiologis.

Dalam pengertian yang lebih luas metode dianggap sebagai cara-cara strategi untuk memahami realitas, langkah-langkah sistematis untuk memecahkan rangkaian sebab akibat berikutnya (Ratna, 2015:34). Metode penelitian sastra adalah cara yang dipilih oleh peneliti dengan mempertimbangkan bentuk, isi, dan sifat sastra sebagai subjek kajian (Endraswara, 2008:8). Metode membutuhkan langkah penelitian yang pantas diakui. Adapun teknik, berhubungan dengan proses pengambilan data dan analisis penelitian.

Dalam mengkaji novel Istana Kedua ini metode penelitian yang digunakan peneliti adalah metode deskriptif analisis. Metode deskriptif analisis dilakukan dengan cara mendeskripsikan faktafakta yang kemudian disusul dengan analisis (Ratna, 2015:53). Metode deskriptif analisis berusaha mendeskriptifkan dan menginterpretasikan apa yang ada dalam novel, baik berupa kondisi atau hubungan yang ada, pendapat yang tumbuh, proses yang berlangsung, akibat atau efek yang terjadi, atau kecenderungan yang telah berkembang pada masa sekarang. Pendeskripsian dan penginterpretasian ini dapat dilakukan melalui penganalisisan terhadap isi novel tersebut. Seluruh novel diteliti secara tuntas mengenai isi ceritanya. Setelah itu baru dikaitkan dengan permasalahan peneliti. Isi cerita yang berkaitan dengan masalah cerita terjadi sebagai tujuan utama pendeskripsian dan penginterpretasian.

Untuk mengetahui langkah dalam melakukan pengkajian data, maka peneliti membuat variabel penelitian. Hal ini dapat diwujudkan dalam bentuk variabel, subvariabel, dan indikator.

Teknik pengumpulan data yang digunakan dalam penelitian ini adalah analisis teks dan teknik dokumentasi, yaitu pengumpulan data-data yang terdapat dalam novel Istana Kedua.

Langkah-langkah pengumpulan data dalam penelitian ini adalah sebagai berikut :

1) Membaca novel yang akan diteliti.

2) Memilih data dan menentukan data yang sesuai dengan masalah. 
Mendokumentasikan bentuk problem rumah tangga dan faktor penyebab yang timbul dalam novel tersebut.

4) Mendeskripsikan hasil observasi, sesuai data-data yang diperoleh.

Setelah data terkumpul, langkah selanjutnya adalah menentukan analisis data, yaitu teknik deskriptif interpretatif. Dalam teknik ini peneliti memaparkan data secara keseluruhan terlebih dahulu, kemudian menafsirkannya (menginterprestasikannya). Untuk menganalisis data dilakukan tahap sebagai berikut :

1) Penguntaian, peneliti mengambil data atau mengumpulkan data yang akan diteliti.

2) Interpretasi, peneliti menguraikan secara terperinci hasil penelitian dari data yang telah dikumpulkan.

3) Evaluasi, mengarah pada evaluasi data yang sudah terkumpul atau terjaring, kemudian menginterprestasikan data tersebut berdasarkan prosedur penelitian yang akan ditentukan.

Sumber data yang digunakan dalam penelitian ini adalah novel yang bernuansa Inspirasi bagi kaum perempuan yang berjudul Istana Kedua karya Asma Nadia. Novel ini diterbitkan oleh PT Gramedia Pustaka Utama bulan Agustus 2007 dengan tebal 248 halaman. Dalam novel ini 9 cerita tokoh yang dikaji yaitu:Arini, Sita, Ratih, Lia, Mbak Pur, Ina, Indri, Ibu Pras, Ibu Arini

Untuk memudahkan langkah-langkah dalam menganalisis data pada penelitian ini, maka peneliti membuat sebuah instrumen penelitian sederhana yang akan digunakan dalam tahapan analisis data.

\section{Hasil dan Pembahasan}

\section{Analisis Bentuk Problem yang Terjadi dalam Cerita Arini}

\section{Selingkuh}

Selingkuh hanya akan menghancurkan ikatan suci yang dibina dalam keluarga. Rasa saling percaya yang menjadi fondasi bahtera keluarga akan hilang. Seorang perempuan sangat paham dan sangat menghayati arti kepercayaan, sehingga begitu ia dilanggar, maka ia menjadi sangat sulit untuk dipulihkan. Selingkuh menghancurkan keluarga tidak hanya dengan merusak kepercayaan.Selingkuh suatu hal atau tindakan yang terjadi pada pasangan lawan jenis. Bentuk problem berupa perselingkuhan yang terdapat dalam novel Istana Kedua karya Asma Nadia ini dapat dilihat dari kutipan di bawah ini:

\section{Kutipan No.1}

Pras, tanpa kekhawatiran sedikitpun, menunjukkan kemesraan pada perempuan lain, di tempat umum pula. Sama sekali tidak peduli itu akan dilihat orang banyak, dan pada akhirnya sampai kepada Arini. (Nadia, 2007:194).

Dari kutipan no.1, menunjukkan bahwa Pras telah menjalin hubungan dengan perempuan lain, sehingga membuat hati istrinya terluka. 


\section{Poligami}

Perkawinan seorang lelaki dengan perempuan lebih dari satu orang. Lihatlah kutipan berikut ini:

\section{Kutipan No. 2}

Tiga jam kemudian, Pras masih berada di rumah sakit. Asyik memandangi bayi kecil di dalam inkubator yang berjuang untuk hidup. Sama sekali tidak menduga, bahwa peristiwa hari itu akan mengantarkannya pada episode kehidupan yang tidak terbayangkan sebelumnya, menikah lagi. (Nadia, 2007:156)

Dalam kutipan no. 2, menunjukkan bahwa Pras telah menikah lagi.

\section{Analisis Faktor Penyebab Timbulnya Problem dalam Cerita Arini}

\section{Faktor dari Suami Istri}

Timbulnya kegoncangan yang bersumber dari suami istri, apabila masalah-masalah tersebut tidak teratasi, seringkali rumah tangga menjadi arena pertarungan sebagai pasar yang gaduh, tidak henti-hentinya adu tawar antara suami istri yang bisa menimbulkan perceraian kedua belah pihak dan membutuhkan penanganan khusus untuk mengatasinya.Problem seringkali muncul, karena adanya konflik peran dan pengkhianatan. Faktor penyebab terjadinya problem yang berupa faktor dari suami istri dalam novel Istana Kedua karya Asma Nadia dapat dilihat dari kutipan di bawah ini:

Kutipan No. 3

Sekarang juga, Arini harus meminta kejujuran laki-laki itu.Tetapi mulut Arini terasa kaku, tertutup rapat seolah terkunci.Suara dari seberang telepon terngiang lagi.Telinganya tak mungkin salah. Arini tak pernah ragu sedetikpun akan apa yang didengarnya pagi tadi. (Nadia, 2007:64).

Dari kutipan no.3, menunjukkan bahwa adanya masalah yang tersembunyi di antara suami istri.

\section{Faktor dari Orang Luar}

Konflik yang ditimbulkan dari pengaruh luar, pada umumnya dari faktor lingkungan sosial atau masyarakat.Yang dimaksud adalah karena pengaruh pihak ketiga atau lingkungan luar keluarga, baik itu tetangga, teman, dan masyarakat.Kehidupan seringkali tidak memenuhi syarat dari segi kesehatan, maupun kesejahteraan, maka berakibat timbulnya banyak kesulitan dan persoalan yang dihadapi, karena lingkungan hidup secara lebih luas dan menyeluruh saling berhubungan dengan semua faktor yang mempengaruhinya.Berbagai perubahan sesuai dengan dinamika kehidupan hendaknya tidak terlalu banyak menimbulkan kegoncangan, yang mudah sekali mempengaruhi kondisi psikis pribadi maupun kelompok. Lihatlah kutipan berikut ini: 


\section{Kutipan No. 4}

Arini mendapatkan sebuah nomor telepon.Tujuh digit angka yang diberikan itu bukan nomor telepon rumah mereka. Tapi perempuan yang mengangkat gagang telepon di sana memperkenalkan dirinya tanpa ragu, membuat Arini serasa tak lagi menapak, limbung dan nyaris terjatuh.

Allah, betulkah cintanya seketika terbang?

Suara itu tegas, jelas, dan riang. Ada celoteh seorang anak di dekatnya ketika perempuan itu menyapa, halo, nyonya Prasetya di sini... (Nadia, 2007:50).

Dari kutipan no. 4, menunjukkan bahwa adanya sosok perempuan yang mengaku sebagai istri Pras, yang membuat Arini sangat terkejut dan terluka.

\section{Analisis Bentuk Problem yang Terjadi dalam Cerita Sita Selingkuh}

Selingkuh hanya akan menghancurkan ikatan suci yang dibina dalam keluarga. Rasa saling percaya yang menjadi fondasi bahtera keluarga tercederai.Seorang perempuan sangat paham tentang arti kepercayaan.Selingkuh menghancurkan keluarga tak hanya dengan merusak kepercayaan.Selingkuh adalah suatu hal atau tindakan yang terjadi pada pasangan lawan jenis. Bentuk problem yang berupa perselingkuhan yang terdapat dalam novel Istana Kedua karya Asma Nadia ini dapat dilihat dari kutipan di bawah ini:

\section{Kutipan No. 5}

Aku mungkin sedih, tapi aku terima kok kalau bang Ilham mau menikah lagi. Sungguh.Tapi jangan dengan perempuan begitu dong. Pakaiannya aja ngasal gitu, masa bang Ilham mau sih? (Nadia, 2007:174).

Dalam kutipan no.5, menunjukkan bahwa suaminya telah menjalin hubungan dengan perempuan lain.

\section{Analisis Faktor Penyebab Terjadinya Problem dalam Cerita Sita}

\section{Faktor dari Suami Istri}

Timbulnya kegoncangan yang bersumber dari suami istri, apabila masalah-masalah tersebut tidak teratasi, seringkali rumah tangga menjadi arena pertarungan sebagai pasar yang gaduh, tidak henti-hentinya adu tawar antara suami istri yang bisa menimbulkan perceraian antara kedua belah pihak dan membutuhkan penanganan khusus untuk mengatasinya.Problem seringkali muncul karena adanya konflik peran dan pengkhianatan. Faktor penyebab terjadinya problem yang berupa faktor dari suami istri dalam novel Istana Kedua karya Asma Nadia dapat dilihat dari kutipan di bawah ini:

Kutipan No. 6

"hm, bang Ilham nggak marah, Ta?

Sita mengangkat bahu.

"marah sih nggak. Cuma lebih banyak diam sekarang.Serbasalah, mungkin.Sebab kalau dia marah, pasti aku anggap dia menyukai perempuan itu." (Nadia, 2007:174). 
Dari kutipan no.6, menunjukkan bahwa adanya masalah yang tersembunyi di antara suami istri.

\section{Faktor dari Orang Luar}

Konflik yang ditimbulkan dari pengaruh luar pada umumnya dari faktor lingkungan sosial atau masyarakat.Yang dimaksudkan adalah karena pengaruh pihak ketiga atau lingkungan luar keluarga, baik itu tetangga, teman, dan masyarakat.Kehidupan yang seringkali tidak memenuhi syarat dari segi kesehatan maupun kesejahteraan, maka berakibat timbulnya banyak kesulitan dan persoalan yang dihadapi, karena lingkungan hidup secara luas dan menyeluruh saling berhubungan dengan semua faktor yang mempengaruhinya.Berbagai perubahan sesuai dengan dinamika kehidupan hendaknya tidak terlalu banyak menimbulkan kegoncangan, yang mudah sekali mempengaruhi kondisi psikis pribadi maupun kelompok.

Lihatlah kutipan berikut ini:

Kutipan no. 7

"satu hal yang aku nggak ngerti...," di samping Arini, Sita menyambung pembicaraan, "Bang Ilham kan biasa aja. Kaya nggak.Ganteng nggak.Kok ya dikejar-kejar.Kalau kamu baca SMS-SMS yang dia kirim untuk Bang Ilham, pasti kepengen muntah juga." (Nadia, 2007:173).

\section{Analisis Bentuk Problem yang Terjadi dalam Cerita Ratih}

\section{Selingkuh}

Selingkuh hanya akan menghancurkan ikatan suci yang dibina dalam keluarga. Rasa saling percaya yang menjadi fondasi bahtera keluarga tercederai.Seorang perempuan sangat paham tentang arti kepercayaan.Selingkuh menghancurkan keluarga tak hanya dengan merusak kepercayaan.Selingkuh adalah suatu hal atau tindakan yang terjadi pada pasangan lawan jenis. Bentuk problem yang berupa perselingkuhan yang terdapat dalam novel Istana Kedua karya Asma Nadia ini dapat dilihat dari kutipan di bawah ini:

Kutipan No. 8

"sebenarnya sudah lama, bu. Cuma tidak ada yang berani bilang. Bapak sering ajak Asih keluar untuk beli obat di apotek, atau beli ini-itu.Selalu sama Asih,” ada tukang cuci yang sudah bertahun-tahun mengikutinya.

Kejadian kedua, terjadi tiga tahun kemudian.Perempuan itu, teman sekantor suaminya.Pegawai baru. Mereka sering jalan bersama. (Nadia, 2007:180).

Ratih lalai memperhatikan perubahan-perubahan suaminya, yang dulu dikira akan ditandainya jika lelaki itu kembali berpaling. Nyatanya, Ratih baru tersentak setelah hubungan suaminya dan perempuan lain itu berjalan setahun. (Nadia, 2007:187).

Dari kutipan no. 8, menunjukkan bahwa suami Ratih telah berselingkuh dua kali.Yang pertama dengan pembantunya, dan yang kedua dengan teman sekantornya. 


\section{Analisis Faktor Peyebab Terjadinya Problem dalam Cerita Ratih}

\section{Faktor dari Suami Istri}

Timbulnya kegoncangan yang bersumber dari suami istri, apabila masalah-masalah tersebut tidak teratasi, seringkali rumah tangga menjadi arena pertarungan sebagai pasar yang gaduh, tidak henti-hentinya adu tawar antara suami istri yang bisa menimbulkan perceraian antara kedua belah pihak dan membutuhkan penanganan khusus untuk mengatasinya.Problem seringkali muncul karena adanya konflik peran dan pengkhianatan. Faktor penyebab terjadinya problem yang berupa faktor dari suami istri dalam novel Istana Kedua karya Asma Nadia dapat dilihat dari kutipan di bawah ini:

Kutipan No. 9

Lelaki bermata hershey'situ menghela napas. Rambut di bagian dahinya yang menyebar tak teratur dan menebarkan aroma kejantanan seolah menggambarkan kekalutan hati.Dia telah menggoreskan luka.Perih membentuk jurang yang semakin lama semakin jelas terbentang, antara dia dan istrinya.Ratih, apa yang bisa kukatakan? Lelaki itu bahkan tak sanggup menjawab pertanyaan-pertanyaan isrinya. (Nadia, 2007:127).

Dalam kutipan no.9, menunjukkan bahwa adanya masalah yang disembunyikan oleh suaminya kepada Ratih, dan suaminya tersebut tidak sanggup untuk menjelaskan masalah tersebut kepada Ratih.

\section{Faktor dari Keluarga}

Konflik yang timbul karena masalah keluarga menuntut perhatian khusus, dengan hubungan pribadi-pribadi dalam keluarga, maka salah seorang anggota keluarga yang memperhatikan kesukaran kepribadian dianggap bermasalah, sehingga bersifat menekan atau menimbulkan kegoncangan dan ketegangan. Lihatlah kutipan berikut ini:

Kutipan No. 10

"waktu Leon sakit, suamimu malah mengurusi Asih.Di rumah sakit dia bukan menemani Leon yang sakit demam berdarah, malah menemani perempuan itu, Ratih.Padahal Asih hanya flu biasa... maafkan Ibu." (Nadia, 2007:181).

Dalam kutipan no.10, menunjukkan bahwa Ibu mertuanya juga ikut diam dan tidak memberitahu Ratih sejak awal bahwa suaminya berselingkuh.

\section{Faktor dari Orang Luar}

Konflik yang ditimbulkan dari pengaruh luar, pada umumnya dari faktor lingkungan sosial atau masyarakat.Yang dimaksudkan adalah karena pengaruh pihak ketiga atau lingkungan luar keluarga, baik itu tetangga, teman, dan masyarakat.Kehudipan yang seringkali tidak memenuhi syaratdari segi kesehatan maupun kesejahteraan, maka berakibat timbulnya banyak kesulitan dan persoalan yang dihadapi, karena lingkungan hidup secara luas dan menyeluruh saling berhubungan dengan semua faktor yang mempengaruhinya.Berbagai perubahan sesuai dengan dinamika 
kehidupan hendaknya tidak terlalu banyak menimbulkan kegoncangan, yang mudah sekali mempengaruhi kondisi psikis pribadi maupun kelompok.

Lihatlah kutipan berikut ini:

Kutipan No. 11

SMS mesra dari nomor yang sama, yang ditemuinya tidak sengaja ketika mencari nomor seseorang di handphone suaminya. Awalnya Ratih tak ingin ambil pusing. Bahkan masih sempat berprasangka baik, sebab siapapun bisa mengirim SMS mesra, dan itu tidak akan menjadikan Ratih paranoid dan mencak-mencak. Tubuhnya baru terasa lunglai,ketika di bagian sent item ia menemukan pesan-pesan yang dikirimkan suaminya ke nomor yang sama, kepada seseorang yang dipanggilnya: cinta. (Nadia, 2007:187).

Dalam kutipan no.11, menunjukkan bahwa kelalaian seorang istri dalam memperhatikan suaminya, dapat mengakibatkan keterlambatan istri untuk mengetahui kalau suaminya telah memiliki perempuan lain. Karena sesungguhnya SMS tersebut dari selingkuhan suaminya.

\section{Analisis Bentuk Problem yang Terjadi dalam Cerita Lia}

Selingkuh

Selingkuh hanya akan menghancurkan ikatan suci yang dibina dalam keluarga. Rasa saling percaya yang menjadi fondasi bahtera keluarga tercederai.Seorang perempuan sangat paham tentang arti kepercayaan.Selingkuh menghancurkan keluarga tak hanya dengan merusak kepercayaan.Selingkuh adalah suatu hal atau tindakan yang terjadi pada pasangan lawan jenis. Bentuk problem yang berupa perselingkuhan yang terdapat dalam novel Istana Kedua karya Asma Nadia ini dapat dilihat dari kutipan di bawah ini:

Kutipan No. 12

Lia tersenyum. Gumpalan asap rokok meluncur dari mulutnya, bermain-main sebentar di udara sebelum perlahan lenyap. Sikapnya tenang sekali ketika berkata," aku melihat mereka, Arini. Di rumahku sendiri.Di kamar cinta kami." (Nadia, 2007:86).

Dari kutipan no.12, dapat kita ketahui, bahwa suami Lia berselingkuh di rumahnya sendiri.

\section{Perceraian}

Perpisahan atau putus hubungan sebagai suami istri dikarenakan masalah rumah tangga yang tidak bisa tertangani dengan baik, sehingga berujung pada perceraian. Berikut kutipannya:

Kutipan No. 13

“kami sudah bercerai." Ucapan itu dilontarkan Lia begitu saja.Tanpa intonasi, begitu ringan seolah bukan sesuatu yang penting. (Nadia, 2007:84). Dari kutipan no.13 di atas, dapat dilihat bahwa Lia dan suaminya bercerai. 


\section{Analisis Faktor Peyebab Terjadinya Problem dalam Cerita Lia}

\section{Faktor dari Suami Istri}

Timbulnya kegoncangan yang bersumber dari suami istri, apabila masalah-masalah tersebut tidak teratasi, seringkali rumah tangga menjadi arena pertarungan sebagai pasar yang gaduh, tidak henti-hentinya adu tawar antara suami istri yang bisa menimbulkan perceraian antara kedua belah pihak dan membutuhkan penanganan khusus untuk mengatasinya.Problem seringkali muncul karena adanya konflik peran dan pengkhianatan. Faktor penyebab terjadinya problem yang berupa faktor dari suami istri dalam novel Istana Kedua karya Asma Nadia dapat dilihat dari kutipan di bawah ini:

Kutipan No. 14

Mungkin seharusnya Lia tidak kuliah dan meninggalkan suaminy bertahuntahun.Laki-laki punya kebutuhan.Mungkin seharusnya mereka bertemu lebih sering. (Nadia, 2007:85). Dalam kutipan no.14, menunjukkan bahwa kurangnya frekuensi pertemuan antara suami istri, dapat mengakibatkan suami berselingkuh.

\section{Analisis Bentuk Problem yang Terjadi dalam Cerita Mbak Pur}

\section{Poligami}

Perkawinan seorang lelaki dengan perempuan lebih dari satu orang.

Lihatlah kutipan berikut ini:

Kutipan No. 15

Madunya Mbak Pur, tetangga mereka, menolak duduk di kursi belakang setiap kali mereka semua pergi jalan-jalan. Dengan congkak perempuan itu minta duduk di depan, di samping suaminya, atau tidak sama sekali. Dan Mas Yadi yang tak ingin ribut, selalu meminta istri pertamanya untuk mengalah dan pindah ke belakang. (Nadia, 2007:103).

Dari kutipan no.15, menunjukkan bahwa Mas Yadi suami Mbak Pur memiliki dua orang istri.

\section{Analisis Faktor Penyebab Terjadinya Problem dalam Cerita Mbak Pur}

\section{Faktor dari Suami Istri}

Timbulnya kegoncangan yang bersumber dari suami istri, apabila masalah-masalah tersebut tidak teratasi, seringkali rumah tangga menjadi arena pertarungan sebagai pasar yang gaduh, tidak henti-hentinya adu tawar antara suami istri yang bisa menimbulkan perceraian antara kedua belah pihak dan membutuhkan penanganan khusus untuk mengatasinya.Problem seringkali muncul karena adanya konflik peran dan pengkhianatan. Faktor penyebab terjadinya problem yang berupa faktor dari suami istri dalam novel Istana Kedua karya Asma Nadia dapat dilihat dari kutipan di bawah ini:

Kutipan No. 16

Yadi tidak mungkin menikah lagi kalau Si Pur bisa merawat diri. (Nadia, 2007:104).

Dari kutipan no.16 dapat diketahui, bahwa istri tidak bisa merawat diri. 


\section{Penutup}

Berdasarkan hasil analisis terhadap novel Istana Kedua Karya Asma Nadia, maka dapat disimpulkan sebagai berikut:

1) Bentuk problem yang terjadi, yaitu:

a. Selingkuh: Pras telah menjalin hubungan dengan perempuan lain, suami telah menjalin hubungan dengan perempuan lain, suami Ratih telah berselingkuh dua kali, suami Lia berselingkuh di rumahnya sendiri, suami Ibu Arini berselingkuh dengan seorang perempuan malam.

b. Poligami: Pras telah menikah lagi, Mas Yadi suami mbak Pur memiliki dua orang istri, suami Ina menikah lagi, pengorbanan seorang istri, karena suaminya menikah lagi, Bapak Pras menikah lagi, suami Ibu Arini telah menikah lagi dengan teman sekolahnya.

c. Perceraian: Lia dan suaminya bercerai.

2) Faktor penyebab timbulnya problem, yaitu:

a. Fakor dari suami istri: Adanya masalah yang tersembunyi di antara suami istri, adanya masalah yang tersembunyi di antara suami istri, adanya masalah yang disembunyikan oleh suaminya kepada Ratih, kurangnya frekuensi pertemuan antara suami istri dapat mengakibatkan suami berselingkuh, istri tidak bisa merawat diri, kesalahan cara berpikir istri, istri yang tidak bisa memasak.

b. Faktor dari keluarga: Ibu mertua juga ikut diam dan tidak memberitahu bahwa suaminya berselingkuh.

c. Faktor dari orang luar: Adanya sosok perempuan yang mengaku sebagai istri Pras, seorang perempuan telah menaksir suaminya, kelalaian seorang istri dalam memperhatikan suaminya, sehingga perempuan lain masuk dalam rumah tangga, ada sosok anak kecil hasil dari pernikahan Bapaknya yang kedua, ada sosok perempuan yang menemui suaminya.

\section{Daftar Rujukan}

Endraswara, Suwardi. 2008. Metodologi Penelitian Sastra. Yogyakarta: Medpress (Anggota IKAPI).

Fajri, Em Zul. 2008. Kamus Lengkap Bahasa Indonesia.Dipa Publisher.

Faruk. 2014. Pengantar Sosiologis Sastra. Yogyakarta: Pustaka Pelajar.

Jamaluddin. 2003. Problematika Pembelajaran Sastra. Yogyakarta: Adicita Karya Nusa.

Mahmud, Nabil Bin Muhammad. Manajemen Rumah Tangga Bahagia. Jakarta: Pustaka at-Tazkia.

Novia, Windy.Kamus Besar Bahasa Indonesia.Surabaya: Kashiko Press.

Nurgiyantoro, Burhan. 2012. Teori Pengkajian Fiksi. Yogyakarta: Gajah Mada University Press. 
Ratna, Kutha Nyoman. 2015. Teori, Metode, dan Teknik Penilaian Sastra. Yogyakarta: Pustaka Pelajar.

Semi, Atar. 1993. Anatomi Sastra. Padang: Angkasa Raya.

Yudiono, K.S. 2007.Pengantar Sejarah Sastra. Jakarta: PT Grasindo.

Tim. 2014.Pedoman Penulisan Skripsi. Banjarmasin: STKIP PGRI

Zaidan, Abdul Rozak, dkk. 2007. Kamus Istilah Sastra. Jakarta: Balai Pustaka. 